\title{
STUDI KEPUASAN KONSUMEN PRODUK KERIPIK TALAS UD SELALU JAYA DI KOTA MATARAM
}

\section{STUDY OF CUSTOMER SATISFACTION OF TARO CHIPS PRODUCTS UD SELALU JAYA IN MATARAM CITY}

\author{
Ni Putu Febri Listanaya Pratami ${ }^{*}$, Tajidan Tajidan², dan I Wayan Suadnya ${ }^{2}$ \\ Program Studi Agribisnis Universitas Mataram, Mataram, Indonesia \\ *Email Penulis korespondensi: tajidan@unram.ac.id
}

\begin{abstract}
ABSTRAK
Penelitian ini bertujuan untuk 1) mengetahui tingkat kepuasan konsumen terhadap produk keripik talas UD Selalu Jaya di Kota Mataram, 2) mengetahui apa saja atribut-atribut keripik talas yang menentukan kepuasan konsumen, 3) mengetahui hubungan antara kualitas produk dengan tingkat kepuasan konsumen keripik talas. Metode yang digunakan dalam penelitian ini adalah metode deskriptif dan teknik pengumpulan data menggunakan angket/kuesioner dan observasi. Penelitian ini dilakukan di Kota Mataram dengan menetapkan tiga kecamatan yaitu Kecamatan Mataram, Kecamatan Selaparang dan Kecamatan Cakranegara. Penentuan responden ditetapkan sebanyak 50 responden, jenis data yang digunakan adalah data kuantitatif dan kualitatif, sedangkan sumber data yang digunakan adalah data primer. Data yang diperoleh dianalisis dengan cara : Uji Validitas dan Reliabilitas, Importance Performance Analysis (IPA), dan Customer Satisfaction Index (CSI). Hasil penelitian mengatakan bahwa tingkat kepuasan konsumen terhadap produk keripik talas UD Selalu Jaya di Kota Mataram yang menggunakan perhitungan Customer Satisfaction Index (CSI) menunjukkan bahwa seluruh konsumen merasa cukup puas, hal ini dapat dilihat dari nilai CSI sebesar 0,64 dengan rentang skala 0,51-0,65.. Atribut-atribut produk keripik talas yang menentukan kepuasan konsumen meliputi atribut produk diantaranya harga, rasa, kemasan, jaminan, dan pelayanan. Hubungan antara kualitas produk dengan tingkat kepuasan konsumen mununjukkan hubungan linearitas positif yaitu semain tinggi kinerja atriribut produk semakin tinggi tingkat kepuasan konsumen. Atribut yang perlu menjadi perioritas untuk ditingkatkan adalah kualitas produk warna bentuk dan aroma.
\end{abstract}

Kata Kunci : atribut, kinerja, kualitas produk.

ABSTRACT
The purposes of this research are to 1) determine the level of consumer satisfaction with taro chips products at UD Selalu Jaya in Mataram City, 2) find out what are the attributes of taro chips that determine customer satisfaction, 3) determine the relationship between product quality and customer satisfaction levels of taro chips. The method used in this research is descriptive method and data collection techniques using a questionnaire / questionnaire and observation. This research was conducted in Mataram City by determining three districts, namely Mataram District, Selaparang District and Cakranegara District. Determination of respondents was determined by as many as 50 respondents, the type of data used was quantitative and qualitative data, while the data source used was primary data. The data obtained were analyzed by 1) Validity and Reliability Test, 2) Importance Performance Analysis (IPA), and Customer Satisfaction Index (CSI).The results of the study said that 1) the level of customer satisfaction with the UD Selalu Jaya taro chips product in the city of Mataram using the calculation of the Customer Satisfaction Index (CSI) shows that all consumers are quite satisfied, this can be seen from the CSI value of 0.64 with a scale range. 0.51-0.65.) The relationship between product quality and the level of consumer satisfaction, the relationship shows a positive linearity relationship, namely the higher the product performance, the higher the level of consumer satisfaction. Attributes that need to be prioritized to be improved are product quality, shape, color and aroma.

Keywords: Attributes, performanc, product qulity. 


\section{PENDAHULUAN}

Sektor pertanian di Indonesia semakin penting karena peranannya yang cukup potensial bagi perekonomian nasional dan perdesaan (Nursan \& Septiadi, 2020), serta mampu mendukung munculnya industri berbahan baku pertanian yang dikenal dengan istilah agroindustri (Harianto, 2014; Ufira Isbah dan Rita Yani Iyan, 2016). Agroindustri merupakan strategi bagi pembangunan pertanian berkelanjutan. Peran agroindustri cukup besar dalam pembangunan pertanian yakni meningkatkan pendapatan, penyerapan tenaga kerja, dan perolehan devisa (Soekartawi, 2000; Hidup Marsudi, 2013), serta menyeimbangkan antara sektor pertanian dengan sektor industri (Supriyati dan Erma Suryani, 2006). Salah satu bahan baku yang kini telah dimanfaatkan sebagai bahan baku industri adalah talas (Wida Rahmawati, et al. 2012)

Menurut Ermayuli et al. (2011) tanaman talas menghasilkan umbi talas sebagai sumber karbohidrat yang memiliki peranan cukup strategis sebagai subtitusi beras. Talas termasuk tanaman umbi-umbian yang dapat digunakan sebagai tanaman pangan dan mempunyai peluang usaha yang menjanjikan (Supriyati dan Erma Suryani, 2006). Menurut R.F Sinaga, et al (2014) bahwa talas merupakan sumber pangan yang penting karena umbinya dapat dijadikan bahan pangan dengan nilai gizi yang cukup baik. Oleh karena kandungan karbohodratnya yang tinggi dan nilai gizi yang berkualitas, maka telah dimanfaatkan sebagai salah satu pemenuhan kebutuhan pangan penduduk sebagai bahan baku keripik dan menghasilkan nilai tambah bagi pelaku usaha (Harnum, 2016).

Hasil penelitian Haerul Iskandar, et al. (2018) bahwa penggorengan keripik talas menggunakan vacum frying pada suhu $90^{\circ}$ lebih disukai oleh panelis. UD Selalu Jaya adalah salah satu industri rumah tangga yang ada di Kota Mataram yang mengolah umbi talas menjadi keripik talas, namun masih menggunakan penggorengan tradional. Salah satu masalah yang tengah dihadapi oleh UD Selalu Jaya adalah persaingan pasar. Persaingan merupakan tantangan bagi UD Selalu Jaya agar tetap eksis dengan cara berinovasi yaitu diversifikasi cita rasa, pemilihan bahan baku yang berkualitas, proses produksi yang higynes, serta perbaikan pengemasan, namun sampai saat ini belum diketahui bagaimana tanggapan dan kepuasan konsumen terhadap produk keripik talas yang diproduksi oleh UD Selalu Jaya. Strategi yang umum diterapkan dalam upaya memperbaiki kinerja pemasaran suatu produk adalah strategi bauran pemasaran (Suhardi, et al., 2019) yang dikenal dengan 4's $\mathrm{P}$ (product, price, place, promotion) sebagai upaya meningkatkan kepusan konsumen.

Kepuasan konsumen merupakan tanggapan emosionall pada evaluasi terhadap pengalaman mengkonsumsi suatu produk atau jasa. Jika konsumen merasa puas terhadap konsumsi suatu produk maka konsumen akan kembali mengkonsumsi produk tersebut, sehingga konsumen akan berlangganan secara tetap. Tetapi jika konsumen merasa tidak puas, maka konsumen tidak akan mengkonsumsi produk itu lagi, bahkan konsumen akan berpindah ke produk lain (Tjiptono, 1997). Kajian tentang kepuasan konsumen menjadi penting untuk dapat merekomendasikan atribut produk mana yang dapat diperbaiki untuk meningkatkan kepuasan konsumen.

\section{METODE PENELITIAN}

Metode yang digunakan dalam penelitian ini adalah metode deskriptif (Moh. Nazir, 1988). Unit analisis dalam penelitian ini adalah konsumen yang membeli dan mengkonsumsi produk keripik talas UD Selalu Jaya. Penelitian ini dilaksanakan di Kota 
Mataram dengan ditetapkan pada tiga kecamatan yaitu Kecamatan Mataram, Kecamatan Cakranegara, dan Kecamatan Selaparang. Responden dalam penelitian ini adalah individu yang pernah/sedang mengkonsumsi produk keripik talas UD Selalu Jaya dan berumur minimal 17 tahun dengan jumlah 50 responden.

Variabel terdiri atas kepuasan konsumen dan atribut produk. Variabel diukur menggunakan skala likert mulai dari sangat tidak setuju sampai dengan sangat setuju dari skor 1 sampai skor 5 (Karlina Aprila, 2020). Pengumpulan data menggunakan angket/kuesioner dan observasi. Data yang diperoleh dianalisis sebagai berikut :

1. Uji Validitas

Uji validitas digunakan untuk mengukur validitas suatu pertanyaan dalam kuesioner. Adapun rumus validitas sebagai berikut :

$$
\begin{array}{cl}
\mathrm{r}= & \frac{N \sum X Y-\left(\sum X\right)\left(\sum Y\right)}{=} \\
\sqrt{ }\left(N \sum X^{2}-\left(\sum X\right)^{2}\right)\left(N \sum Y^{2}-\left(\sum Y\right)^{2}\right) \\
\text { Keterangan : } \\
\mathrm{r} \quad=\text { koefisien } \\
\mathrm{X} \quad=\text { variabel kepuasan konsumen } \\
\mathrm{Y} \quad=\text { variabel atribut produk } \\
\mathrm{N} \quad=\text { jumlah keseluruhan data }
\end{array}
$$

2. Uji Reliabilitas

Uji reliabilitas digunakan untuk mengukur indikator dari variabel penelitian. Adapun rumus reliabilitas sebagai berikut :

$$
r_{a c}=\left(\frac{k}{k-1}\right)\left[1-\frac{\sum \sigma_{b}^{2}}{\sigma_{t}^{2}}\right]
$$

Keterangan :

$\mathrm{r}=$ koefisien reliabilitas alfa cronbach

$\mathrm{k}=$ jumlah butir pertanyaan

$\sigma \mathrm{i}^{2}=$ variansi butir- butir pertanyaan

$\sigma^{2}=$ variansi skortest

3. Importance Performance Analysis (IPA)

Metode ini menentukan penting dan tidaknya atribut produk oleh konsumen, selain itu metode ini juga menentukan apakah konsumen puas atau tidak dalam mengkonsumsi produk keripik talas UD Selalu Jaya.

Berikut adalah tahapan dalam metode Importance Performance Analysis (IPA) (Santoso, 2011).

Tahap pertama adalah menghitung rata-rata untuk setiap atribut dengan rumus:

$$
\overline{X i}=\frac{\sum_{i=1}^{\overline{2}} X i}{n} \quad \bar{Y} i=\frac{\sum_{i=1}^{k} Y i}{n}
$$

Keterangan :

$\overline{X I}=$ bobot rata-rata tingkat penilaian atribut kinerja ke-i

$\overline{Y I}=$ bobot rata-rata tingkat penilaian atribut kepentingan ke-i

$n=$ jumlah responden

Tahapan terakhir yaitu penjabaran tiap atribut dalam diagram kartesius. Berikut penjelasan untuk masing-masing kuadran dalam diagram kartesius:

a. Kuadran I (Prioritas Utama) tingkat kinerja tinggi tetapi tidak memuaskan konsumen

b. Kuadran II (Pertahankan Prestasi) tingkat kinerja dan kepuasan tinggi. 
c. Kuadran III (Prioritas Rendah) tingkat kinerja dan kepuasan rendah.

d. Kuadran IV (Berlebihan) faktor yang kurang penting dan berlebihan.

4. Customer Satisfaction Index (CSI)

Customer Satisfaction Index (CSI) atau yang lebih dikenal dengan indeks kepuasan konsumen merupakan metode yang digunakan untuk menentukan tingkat kepuasan konsumen secara menyeluruh. Menghitung Customer Satisfaction Index (CSI), yaitu nilai yang diperoleh dari perhitungan CSI digunakan untuk mengetahui tingkat kepuasaan konsumen. Dalam penelitian ini menggunakan skala 5 kemudian dikalikan 100 persen. Dihitung dengan rumus:

$$
C S I=\frac{\sum_{i=1}^{P} \text { wsi }}{\text { Lebar skala yang digunakan }} \times 100
$$

\section{HASIL DAN PEMBAHASAN}

\section{Karakteristik Responden} pekerjaan.

Karakter responden pada penelitian ini dilihat dari jenis kelamin, usia, dan

\section{Jenis Kelamin}

Berdasarkan data jenis kelamin responden diketahui bahwa yang mengkonsumsi keripik talas UD Selalu Jaya adalah perempuan yang berjumlah 35 orang dengan persentase $70 \%$ sedangkan laki-laki berjumlah 15 orang dengan persentase $30 \%$. Konsumen yang paling banyak mengkonsumsi keripik talas adalah perempuan karena pada dasarnya perempuan memiliki ketertarikan dan cenderung suka berbelanja dibandingkan laki-laki.

\section{Usia}

Berdasarkan Tabel 1 menunjukkan bahwa sebagian besar konsumen keripik talas UD Selalu Jaya memiliki rentang usia 37-46 tahun dengan jumlah persentase 26\%. Hal ini menunjukkan bahwa konsumen dengan rentang usia 37-46 tahun merupakan golongan usia produktif bekerja serta memiliki pemahaman yang cukup dalam pengambilan keputusan untuk membeli suatu produk. Selain itu para konsumen dengan usia produktif ini memiliki pengetahuan yang matang terkait manfaat suatu produk.

Tabel 1. Karakter Responden Berdasarkan Usia

\begin{tabular}{ccc}
\hline Umur & Frekuensi & Persentase (\%) \\
\hline $17-26$ & 12 & 24 \\
$27-36$ & 10 & 20 \\
$37-46$ & 13 & 26 \\
$47-56$ & 11 & 22 \\
$57-66$ & 4 & 8 \\
\hline Total & 50 & 100 \\
\hline
\end{tabular}

Sumber : Data Primer diolah, 2021

\section{Pekerjaan}

Berdasarkan Tabel 2 menunjukkan bahwa konsumen dengan pekerjaan PNS adalah mayoritas konsumen keripik talas UD Selalu Jaya dengan jumlah 18 orang atau $36 \%$. UD Selalu Jaya lebih banyak memasarkan produknya ke perkantoran dan sekolah, sehingga tampak konsumen yang lebih banyak yaitu PNS. 
Tabel 2. Karakteristik Responden Berdasarkan Pekerjaan

\begin{tabular}{lcc}
\hline \multicolumn{1}{c}{ Pekerjaan } & Frekuensi & Persentase (\%) \\
\hline Pelajar & 3 & 6 \\
Mahasiswa & 6 & 12 \\
PNS & 18 & 36 \\
Karyawan Swasta & 8 & 16 \\
Pedagang & 6 & 12 \\
Ibu Rumah Tangga & 6 & 12 \\
Lain- Lain & 3 & 6 \\
\hline Total & 50 & 100 \\
\hline
\end{tabular}

Sumber : Data Primer diolah, 2021

\section{Validitas Data dan Reliabelitas Instrumen}

1. Uji Validitas Tingkat Kepuasan Konsumen

Berdasarkan hasil pengujian 21 indikator dapat mengumpulkan data secara tepat serta digunakan untuk mengukur tingkat kepuasan konsumen terhadap produk keripik talas UD Selalu Jaya. Hasil analisis validitas menunjukkan koefisien $r$ hitung $>r$ tabel, artinya kepuasan konsumen terhadap produk kriik talas tergolong valid.

2. Uji Validitas Atribut-Atribut Produk Keripik Talas

Berdasarkan hasil pengujian 21 indikator dapat mengumpulkan data secara tepat serta dapat digunakan untuk mengukur atribut-atribut keripik talas yang menentukan kepuasan konsumen. Hasil nalisis menunjukkan bahwa $r$ hitung $>r$ tabel, artinya atributatribut prodyj keripik talas dapat menentukan kepuasan konsumen.

3. Uji Validitas Hubungan Antara Kualitas Produk Dengan Tingkat Kepuasan Konsumen Keripik Talas

Berdasarkan hasil pengujian 21 indikator dapat mengumpulkan data secara tepat serta digunakan untuk mengukur hubungan antara kualitas produk dengan tingkat kepuasan konsumen dikarenakan $r$ hitung $>r$ tabel.

4. Uji Reliabilitas Instrumen Tingkat Kepuasan Konsumen Terhadap Produk Keripik Talas UD Selalu Jaya

Berdasarkan hasil uji reliabilitas diketahui bahwa tingkat kepuasan konsumen terhadap produk keripik talas UD Selalu Jaya di Kota Mataram dengan nilai koefisien $78,9 \%$ dinyatakan dapat dipercaya (reliabel) dikarenakan $\alpha>0,6$ atau $\alpha>60 \%$.

5. Uji Reliabilitas Atribut-Atribut Produk Keripik Talas Yang Menentukan Kepuasan Konsumen

Berdasarkan hasil uji reliabilitas diketahui bahwa atribut-atribut keripik talas yang menentukan kepuasan konsumen dengan nilai koefisien $87,6 \%$ dinyatakan dapat dipercaya (reliabel) dikarenakan $\alpha>0,6$ atau $\alpha>60 \%$.

6. Uji Reliabilitas Hubungan Antara Kualitas Produk Dengan Tingkat Kepuasan

Konsumen Keripik Talas

Berdasarkan hasil uji reliabilitas diketahui bahwa hubungan antara kualitas produk dengan tingkat kepuasan konsumen keripik talas dengan nilai koefisien $86,5 \%$ dinyatakan dapat dipercaya (reliabel) $\alpha>0,6$ atau $\alpha>60 \%$. 


\section{Tingkat Kepuasan Konsumen Terhadap Produk Keripik Talas UD Selalu Jaya}

Untuk mengukur tingkat kepuasan konsumen secara keseluruhan digunakan metode Customer Satisfaction Index (CSI). Berdasarkan hasil perhitungan CSI diketahui nilai dari Mean Satisfaction Score (MSS) sebesar 59,95 dengan nilai tertinggi terdapat pada indikator yang mengatakan bahwa pelayanan sopan dan ramah dengan nilai sebesar 4,66 karena dalam melayani konsumen owner dan karyawan bersikap sopan dan ramah sehingga kinerjanya menjadi pengaruh besar untuk kepuasan konsumen, dan nilai terendah terdapat pada indikator produk keripik talas memiliki daya tahan yang awet dengan nilai sebesar 1,58 karena produk keripik talas tidak bisa bertahan lama sehingga konsumen merasa bahwa kinerjanya ini tidak memuaskan konsumen.

Nilai dari Weighting Score (WS) sebesar 3,20 dengan nilai tertinggi terdapat pada indikator pelayanan sopan dan ramah dengan nilai sebesar 0,29 sedangkan nilai terendah terdapat pada indikator aroma keripik talas menggugah selera konsumen dengan nilai sebesar 0,06. Menentukan nilai Customer Satisfaction Index (CSI), maka jumlah nilai Weighting Score (WS) sebesar 3,20 dibagi dengan rentang kelas yang digunakan sebesar 5 yang merupakan kriteria kepuasan konsumen. Hasil perhitungan nilai CSI dengan menggunakan skor rata-rata tingkat kinerja dan kepuasan maka diperoleh nilai sebesar $64 \%$ atau 0,64 index kepuasan konsumen yang berada pada kisaran 0,51-0,65 yang artinya secara keseluruhan konsumen produk keripik talas UD Selalu Jaya merasa cukup puas.

\section{Atribut-Atribut Produk Keripik Talas Yang Menentukan Kepuasan Konsumen}

Untuk mengukur atribut-atribut keripik talas yang menentukan kepuasan konsumen menggunakan metode Importance Performance analysis (IPA). Hasil dari 21 indikator diketahui bahwa jumlah atribut (X) diperoleh nilai sebesar 60,15 dengan perolehan rata-rata 2,86 dan jumlah tingkat kepuasan (Y) sebesar 59,95 dengan perolehan rata-rata 2,85. Pengaruh atribut-atribut produk keripik talas terhadap kepuasan konsumen dipetakan melalui penggambaran letak masing-masing atribut pada setiap kuadran dalam diagram kartesius yang terbagi kedalam empat kuadran yang ditetapkan berdasarkan nilai kepuasan dengan nilai atribut-atribut produk dapat dilihat pada Gambar 1.

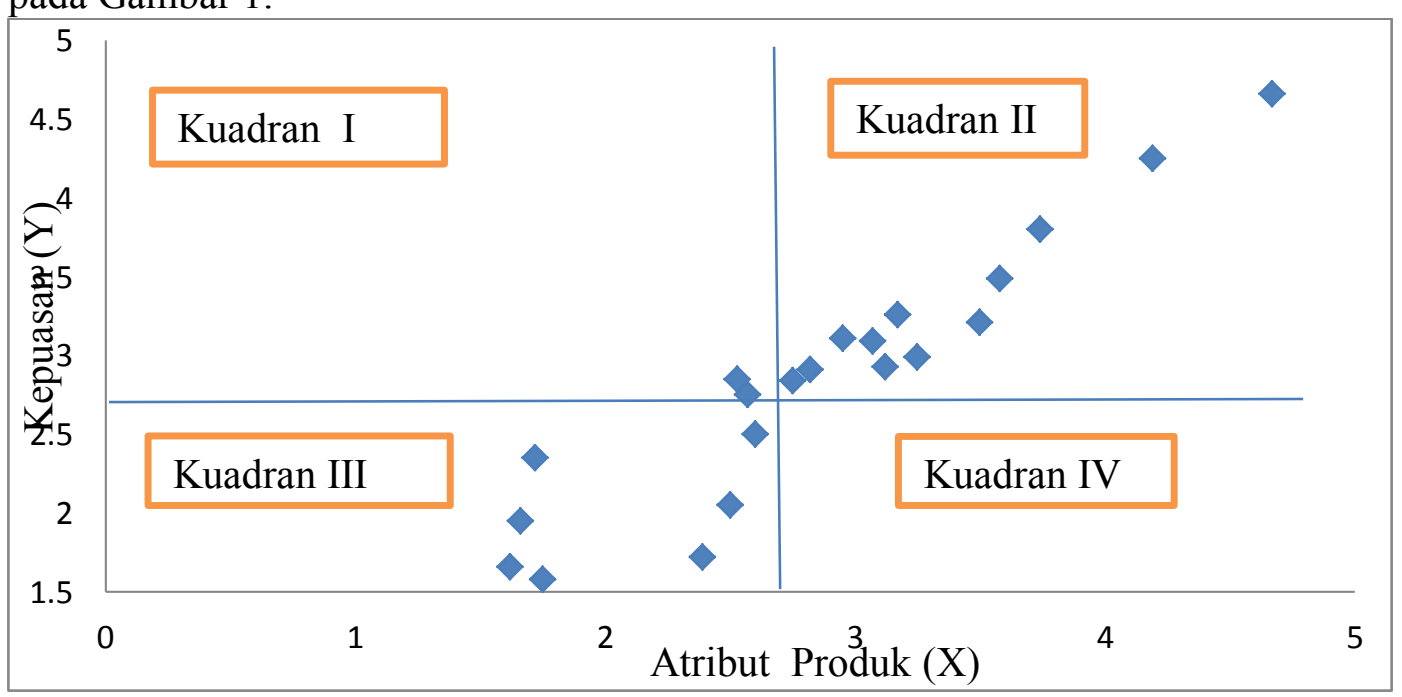

Gambar 1. Nilai Atribut-Atribut Produk dan Kepuasan

Berdasarkan diagram kartesius yang disajikan pada Gambar 1 diketahui bahwa atribut-atribut produk keripik talas UD Selalu Jaya yang menentukan kepuasan konsumen terletak pada kuadran II (pertahankan prestasi) dengan jumlah keseluruhan 
lima atribut yang meliputi harga (X1), rasa (X3), kemasan (X4), warna (X5), bentuk (X6), dan aroma (X7) yang termasuk didalamnya 12 indikator.

Hasil penelitian sebagaimana diuraikan di atas masih relevan dengan hasil penelitian Yolanda, et al, (2020) adalah atribut harga produk (X1) dan rasa (X3), sementara atribut lainnya seperti kemasan (X4), warna (X5) dan aroma (X7) berbeda. Hasil penelitian Yolanda, et al. (2020) menunjukkan bahwa atribut produk yang harus diprioritaskan untuk ditingkatkan adalah variasi rasa, penjualan dan promosi online, lokasi toko, seragam pegawai, karyawan berpenampilan rapi, proses pembayaran, penyesuaian tampilan produk, dan label harga produk.

\section{Hubungan Antara Kualitas Produk Dengan Tingkat Kepuasan Konsumen Keripik Talas}

Untuk mengukur hubungan antara kualitas produk dengan tingkat kepuasan konsumen digunakan metode Importance Performance Analysis (IPA). Hasil dari 21 indikator diketahui bahwa jumlah kinerja $(X)$ diperoleh nilai sebesar 59,24 dengan perolehan rata-rata 2,82 dan jumlah tingkat kepuasan (Y) sebesar 59,95 dengan perolehan rata-rata 2,85. Hubungan antara kualitas produk dengan tingkat kepuasan konsumen dipetakan melalui penggambaran letak masing-masing atribut pada setiap kuadran dalam diagram kartesius yang dapat dilihat pada Gambar 2.

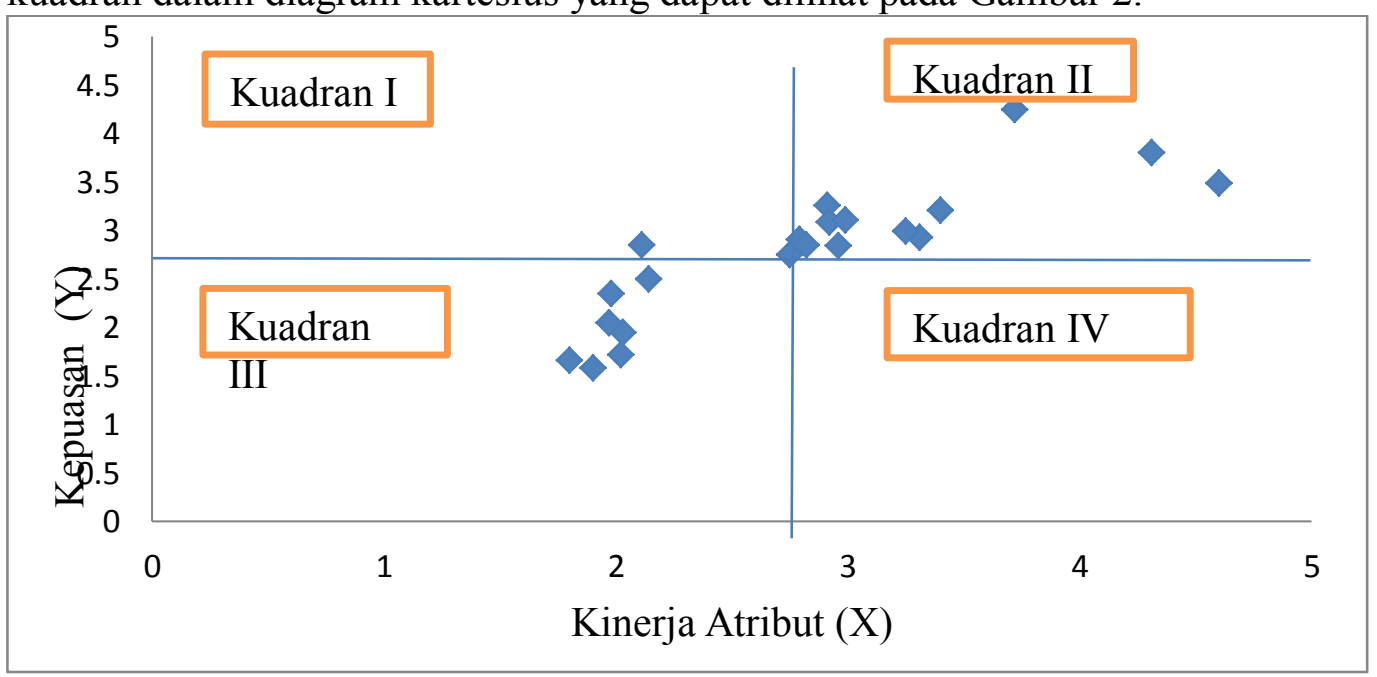

Gambar 2. Nilai Kinerja dan Kepuasan

Berdasarkan hasil diagram kartesius pada Gambar 2 dapat tampak terbangun hubungan yang linear positif antara tingkat kepuasan konsumen dengan kinerja pemasaran UD Selalu Jaya yang mana semakin tinggi tingkat kepuasan konsumen menunjukkan semakin membaiknya kinerja pemasaran UD Selalu Jaya. Sebaran maching data terjadi pada kuadran III dan kuadran II. Uraian detilnya sebagai berikut: Kuadran I (Prioritas Utama)

Atribut yang berada pada kuadran ini dianggap memiliki tingkat kinerja yang tinggi akan tetapi kurang memuaskan konsumen, sehingga produsen produk keripik talas UD Selalu Jaya dapat melakukan perbaikan dengan kinerja yang lebih baik lagi dan dapat memuaskan konsumen. Terdapat dua atribut yaitu kualitas produk (X2), dan rasa $(\mathrm{X} 3)$

Kuadran II (Pertahankan Prestasi)

Kuadran II merupakan mempertahankan prestasi adalah posisi yang menunjukkan kinerja yang sudah sesuai dengan apa yang diharapkan konsumen, 
sehingga pihak UD Selalu Jaya hendaknya tetap mempertahankan prestasi kinerjanya. Atribut-atribut yang berada pada kuadran ini dianggap sangat mempengaruhi kepuasan konsumen, sehingga terdapat lima atribut yang berada pada kuadran ini meliputi harga (X1), rasa (X3), kemasan (X4), jaminan (X8) dan pelayanan (X9). Lima atribut produk ini harus dipertahankan oleh UD Selalu Jaya karena sangat mempengaruhi kepuasan konsumen.

Kuadran III (Prioritas Rendah)

Atribut-atribut produk pada kuadran ini tidak mempengaruhi kepuasan konsumen, disamping itu kinerja atribut produk ini kurang maksimal pada kualitas produk (X2), warna (X5), bentuk (X6) dan aroma (X7). Oleh karena itu sebagai prioritas perbikan kinerja atribut produk yang diperioritaskan adalah kualitas produk, warna, bentuk, dan aroma. Pemanfaatan vacum frying merupakan solusi yang dapat meningkatkan keempat atribut tersebut.

\section{KESIMPULAN DAN SARAN}

\section{Kesimpulan}

Tingkat kepuasan konsumen terhadap produk keripik talas UD Selalu Jaya di Kota Mataram yang menggunakan perhitungan Customer Satisfaction Index (CSI) menunjukkan bahwa secara keseluruhan konsumen merasa cukup puas terhadap produk keripik talas, hal ini dapat dilihat dari nilai CSI sebesar 0,64 dengan rentang skala 0,510,65 .

Atribut-atribut produk yang menentukan kepuasan konsumen terdapat pada kuadran II (Pertahankan prestasi) meliputi lima atribut produk diantaranya harga (X1), rasa (X3), kemasan (X4), jaminan (X8), dan pelayanan (X9). Hal ini dikarenakan lima atribut produk dianggap memiliki kinerja yang tinggi dan sangat menentukan kepuasan konsumen.

Hubungan antara kualitas produk dengan tingkat kepuasan konsumen keripik talas yang dipetakan dalam empat kuadran yaitu kuadran I (prioritas utama) memiliki tingkat kinerja yang tinggi akan tetapi tingkat kepuasan konsumen yang rendah terdapat dua atribut produk yaitu kualitas produk (X1), dan rasa (X3) dengan masing-masing posisi responden pada setiap atribut 5\% dan 15\%, kuadran II (pertahankan prestasi) tingkat kinerja yang tinggi diimbangi dengan tingkat kepuasan konsumen yang tinggi kuadran ini ditempati lima atribut meliputi harga (X1), rasa (X3), kemasan (X4), jaminan (X8) dan pelayanan (X9) dengan masing-masing posisi responden pada setiap atribut $20 \%, 15 \%, 15 \%$ dan $15 \%$, kuadran III ( prioritas rendah) kuadran yang memiliki tingkat kinerja dan tingkat kepuasan konsumen yang rendah, kuadran ini ditempati oleh empat atribut produk yaitu kualitas produk (X2), warna (X5), bentuk (X6) dan aroma (X7) dengan masing-masing posisi responden pada setiap atribut 5\%, 5\%, 5\% dan 5\%. Hal ini menunjukkan bahwa produsen harus memperbaiki kinerja atribut ini agar meningkatkan kepuasan konsumen.

\section{Saran}

Berdasarkan hasil penelitian dan kesimpulan yang telah diuraikan, maka dapat diajukan saran agar produsen keripik talas UD Selalu Jaya sebaiknya mengamati atribut produk yang harus dipertahankan, diperbaiki, terdapat lima atribut produk disukai serta memuaskan konsumen yang harus dipertahankan, dan sebaiknya juga demi kelangsungan usaha ini produsen memiliki hubungan dan kerjasama yang baik terhadap petani talas untuk mendapatkan bahan baku secara tetap agar proses produksi keripik 
talas berjalan dengan lancar. Penggorengan keripik talas oleh UD Selalu Jaya sebaiknya menggunakan vacum frysing pada suhu $90^{\circ}$ Cencius.

Peneliti selanjutnya diharapkan agar dapat melakukan penelitian lebih rinci dan detail mengenai pengembangan atribut produk keripik talas UD Selalu Jaya yang berpengaruh terhadap kepuasan konsumen.

\section{DAFTAR PUSTAKA}

Ermayuli, Ismono, H., \& Setyani, S. (2011). Analisis Teknik dan Finansial Agroindustri Skala Kecil pada Berbagai Proses Pembuatan Keripik Talas di Kabupaten Lampung Barat. J. Teknologi dan Industri Hasil Pertanian: 16 (1):82-90.

Iskandar, H.,Patang, \& Kadirman, (2018). Pengolahan Talas (Colocasia Esculenta L., Schott) Menjadi Keripik Mengunakan Vacum Frying dengan Variasi Waktu. Jurnal Pendidikan Teknologi Pertanian, 4(1): 29-42.

Harianto, (2014). Peranan Sektor Pertanian Dalam Ekomian Perdesaan. Pusat Studi Pembangunan dan Perdesaan Instutut Pertanian Bogor: Bogor. https://pse.litbang.pertanian.go.id $>$ ind $>$ pdffile

Harnum, (2016). Analisis Nilai Tambah Keripik Talas Priangan Pada Industri Rumah Tangga Darmatian Product di Kota Palu. e-J. Agrotekbis 4 (6) : 725 - 731.

Marsudi,H. (2013). Kajian Agroindustri Berbasis Masyarakat Kabupaten Karang Anyar. Jurnal Riset Manajemen \& Akuntansi, 4 (7): 21-44.

Aprillahm, K. (2020). Teknik Penyusunan Skala Linkert. Fakultas Ekonomi dan Bisnis Universitas Diponegoro.

Nazir, M. 1988. Metode Penelitian. Ghalia Indonesia: Jakarta.

Nursan, M., \& Septiadi, D. (2020). Penentuan Prioritas Komoditas Unggulan Peternakan di Kabupaten Sumbawa Barat. Jurnal Agribisnis Dan Ilmu Sosial Ekonomi Pertanian, 5(1), 29-34.

Rahmawati, W., Kusumastuti, Y.A., Aryanti, A. (2012). Karakteristik Pati Talas (Colocasia escuenta (L.) Schott) Sebagai lternatif Sumber Pati Industri di Indonesia. Jurnal Teknologi Kimia dan Industri. 1 (1): 347-351. https://ejournal3.undip.ac.id/index.php/jtki/article/view/947

Sinaga,R.F., Ginting, G.M., Hendra, M., Ginting, S., \& Hasibuan, R. (2014). Pengaruh Penambahan Gliserol Terhadap Sifat Kekuatan Tarik dan Pemanjangan Saat Putus Bioplastik Dari Pati Umbi Talas. Jurnal Teknik Kimia USU, 3 (2): 19-24. https://talenta.usu.ac.id/jtk/article/view/1608/1090

Santoso, (2011). Persepsi Konsumen Terhadap Kualitas Bakpao Telo Dengan Metode Importance Performance Analysis (IPA). Jurnal Teknologi Pertanian, 12 (1) : 9.

Soekartawi, (2000). Pengantar Agroindustri. Raja Grafindo Persada: Jakarta.

Suhandi, Hanafiah, H., \& Harsono, P. (2019). Strategi Pemasaran Makanan Tradisional Keripik Talas Beneng dengan Penerapan Marketing Mix Untuk Meningkatkan Penjualan. Jurnal Riset Bisnis dan Manajemen, 10 (2): 144-152.

Supriyati \& Suryani, E. (2006). Peranan, Peluang dan Kendala Pengembangan Agroindustri di Indonesia. Jurnal Forum Peneliti Agro Eonomi, 24 (2): 92-106.

Tjiptono, Fandy. (1997). Strategi Pemasaran, Edisi Kedua. Andi: Yogyakarta.

Isbah, U., \& Iyan, R.Y. (2016). Analisis Peran Sektor Pertanian Dalam Perekonomian dan Kesemoatan Kerja di Provinsi Riau. Jurnal Sosial Ekonomi Pembangunan. 7(19): 45-46. 
Yolanda, V., Suyono, Wijayanti, I.K.E. (2020). Analisis Kepuasan Konsumen Terhadap Produk Keripik Salak UMKM Salak Cristal Di Kecamatan Turi Kabupaten Sleman Yogyakarta. Forum Agribisnis : Agribusiness Forum, 10 (2) :131-144. DOI:https://doi.org/10.29244/fagb.10.2.131-144. 